\title{
Introduction: Jesuits in Asian-Pacific Borderlands
}

\author{
Alexandre Coello de la Rosa \\ Universitat Pompeu Fabra (UPF/CSIC) - ICREA Academia, Barcelona, Spain \\ alex.coello@upf.edu
}

\begin{abstract}
In the last years, a growing number of scholars of world history have focused on Jesuit networks, economic and cultural interactions in the Asian-Pacific territories. This introduction and the essays contained within the pages of this special issue bring religious mobility to the foreground, putting special emphasis on the way how "conversion" (both religious and cultural) transformed the trans-Pacific frontier into a zone of sustained contact and transculturation involving Europe, Asia, and the Americas. First, it explores contending networks of evangelization, which revolve around a basic premise: they were heterogeneous and uncoordinated, moving in unexpected and complex directions. Second, it analyzes the way in which Jesuit evangelization effected a "tricultural convergence" of Asian, Iberian, and indigenous cultures towards the production of a "global consciousness." Finally, it examines a metahistory of Iberian globalization and empire, which emphasized a failed hegemony over Islamic territories of southern Philippines as much as diminished the native Filipino as historical subject.
\end{abstract}

\section{Keywords}

Jesuits - borderlands - early modern Pacific - globalization - Philippines - conversion - Iberian empire 


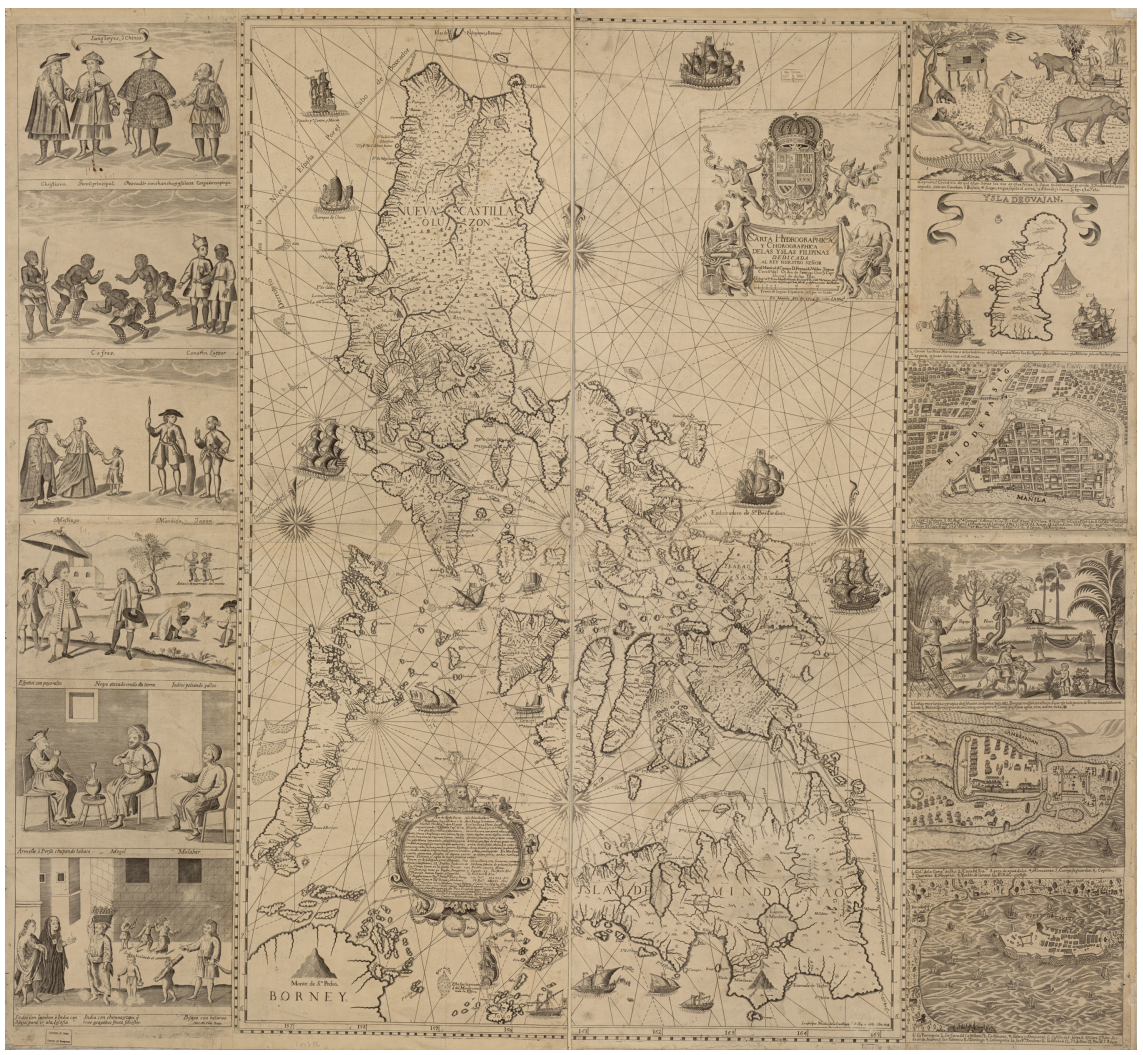

figure 1 Pedro Murillo Velarde, S.J. \& Nicolás de la Cruz Bagay, Carta hydrographica y chorographica de las Yslas Filipinas...[Manila, 1734], Library of Congress, https:// www.loc.gov/item/2013585226/.

While most pioneering and contemporary scholars of world history and "soft globalization" focus upon economic and cultural interactions within trading networks among Western Europe, West Africa, Asia, and the American territories, ${ }^{1}$ our contribution aims to bring religious mobility to the foreground,

1 André Gunder Frank, ReORIENT: Global Economy in the Asian Age (Berkeley: California University Press, 1998); Serge Gruzinski, "Les mondes méles de la monarchie catolique et autres: 'Connected Histories,' Annales: Histoire, sociétés, sciences sociales 56, no. 1 (2001): 85117; Gruzinski, Les quatre parties du monde: Histoire d'une mondialisation (Paris: La Martinière, 2004); Dennis O. Flynn, Arturo Giráldez, and Richard von Glahn, eds., Global Connections and Monetary History, 1470-180o (Burlington: Ashgate, 2003); François Gipouloux, La Mediterránee asiatique: Villes portuaires et réseaux marchands en Chine, au Japon et en Asie du Sud-Est XVIeXXIe siècle (Paris: CNRS Éditions, 2009); Jan de Vries, "The Limits of Globalization in the Early 
thereby revealing the transpacific axis not only as a new commercial network between the Philippines and the southeast and western Mexican seaboards but also as a missionary and geo-political network. ${ }^{2}$ This special issue seeks to underline the centrality of the Jesuits as agents in the making of the modern world, with particular attention to the "conversion" (both religious and cultural) of the trans-Pacific frontier into a zone of sustained contact and transculturation involving Europe, Asia, and the Americas (see Figure 1).

The Society of Jesus, sponsored by Portugal and Spain, played a crucial role in spreading out Roman Catholicism-ius predicandi-in the age of early modern globalization. ${ }^{3}$ Using the city of Manila as a platform to reach other Asian and Oceanic territories, the Jesuit missionaries were able to expand to the Ming's southern China (Iaccarino), to the sultanates of Mindanao and Sulu in southern Philippines (Crailsheim, Coello, Rodríguez), and to the distant Mariana Islands (Peña), where no Islamic nor "heretic nations" had yet reached these Asia-Pacific borderlands. However, the "spiritual conquest" ("the cross") of the Philippines cannot be analyzed separately from legitimized violence of the conquest ("the sword"), which had catastrophic effects on native populations, just as it had in the Americas. ${ }^{4}$

This special issue rethinks Jesuit history in the Philippines (sixteenth to eighteenth centuries) by focusing on three major themes. First, it explores contending networks of evangelization, which revolve around a basic premise: they were

Modern World," The Economic History Review 63, no. 3 (2010): 710-33; Sanjay Subrahmanyam, Aux origines de l'histoire globale (Paris: Fayard, 2014); Arturo Giráldez, The Age of Trade: The Manila Galleons and the Dawn of the Global Economy (Lanham, MD: Rowman \& Littlefield Publishers, 2015).

2 Brandon Bayne, "Converting the Pacific: Jesuit Networks between New Spain and Asia," in The [Oxford] Handbook of Borderlands of the Iberian World, ed. Danna A. Levin Rojo and Cynthia Radding (Oxford: Oxford University Press, 2018), 2, doi: 10.1093/oxfordhb/9780199341771.013.2 (accessed October 30, 2021).

3 Luke Clossey, "Merchant, Migrants, Missionaries, and Globalization in the Early Modern Pacific," Journal of Global History 1, no. 1 (2006): 41-58, doi:https://doi.org/10.1017/S1740022806000039 (accessed October 30, 2021); Clossey, Salvation and Globalisation in the Early Jesuit Mission (Cambridge: Cambridge University Press, 2008); Charlotte de Castelnau-L'Estoile, Marie-Lucie Copete, Aliocha Maldavsky, and Ines G. Županov, eds. Missions d'évangélisation et circulation des savoirs, xvié-xviiié siècle (Madrid: Casa de Velázquez, 2011), 1-22; Guillermo Wilde, Saberes de la conversión: Prácticas jesuíticas y escrituras de la alteridad en los confines coloniales (Buenos Aires: Editorial sB, 2012); Alexandre Coello, Javier Burrieza, and Doris Moreno, eds., Jesuitas e imperios de ultramar (Madrid: Sílex, 2012); Thomas Banchoff and José Casanova, eds., Jesuits and Globalization: Historical Legacies and Contemporary Challenges (Washington, DC: Georgetown University Press, 2016).

4 Matthew Restall, "Legitimised Violence in Colonial Spanish America," in The Cambridge World History of Violence (The Cambridge World History of Violence), ed. Robert Antony, Stuart Carroll, and Caroline Dodds Pennock (Cambridge: Cambridge University Press, 2020), 408-26. 
heterogeneous and uncoordinated, moving in unexpected and complex directions. A comparative analysis is absolutely essential before reaching a definite understanding of the role of Catholic colonialism in the early modern Philippines. Which were the contending networks of evangelization? How did the slow pace of implementation of the Tridentine reforms affect political and religious configuration in the Philippines and elsewhere? Which were the interactions and engagements between the church's universalist principles and local political actors? And how local realities forced the missionaries to imagine sophisticated methods of accommodation and hybridization? As Ubaldo Iaccarino (Institute of Taiwan History, Academia Sinica, Taiwan) points out, Manila turned into a stepping-stone for other religious orders, like the Franciscans, to reach southern China. The mission of Pedro de Alfaro of 1579 is a case in point on the importance of seeing the Franciscan mission as an attempt to continue the original efforts of Augustinian missionaries, as well as its significance to the larger history of missionary attempts to unsuccessfully penetrate China.

Secondly, it analyzes the way in which Jesuit evangelization effected a "tricultural convergence" of Asian, Iberian, and indigenous cultures towards the production of a "global consciousness." ${ }^{5}$ One that was not just commercial but also missionary, thereby bringing religious mobility across Spain's far-flung Pacific outposts to the foreground. ${ }^{6}$ At the turn of the sixteenth century into the eighteenth century, silver-laden galleons made their way across the mare clausum (closed sea) of the Pacific Ocean almost annually, which turned them into the most important source of revenues for the Spanish elites of Manila. ${ }^{7}$ However, this transpacific axis should be understood not only as an imperial commercial circuit between the Philippines, the Southeast Asian world, and the New Spain's seaboards but also as a missionary network for gathering knowledge among European, American, Asian, and Oceanic peoples, thereby putting the church's maneuvering in the spotlight (Peña, Coello). Jesuit missionaries gathered information about "cultural borders" of the early modern colonial Philippines, using witness-based (autoptic) knowledge and empirical practices. $^{8}$

5 Rainer F. Buschmann, Edward R. Slack, and James B. Tueller, eds., Navigating the Spanish Lake: The Pacific in the Iberian World, 1521-1898 (Honolulu: University of Hawai'i Press, 2014), 64.

6 Bayne, "Converting the Pacific," 1-31.

7 William Lytle Schurtz, El galeón de Manila (Madrid: Ediciones de Cultura Hispánica, [1939] 1992); Antonio-Miguel Bernal, "La 'Carrera del Pacífico': Filipinas en el sistema colonial de la Carrera de Indias," in España y el Pacífico: Legazpi, ed. Leoncio Cabrero, 2 vols. (Madrid: Sociedad Estatal de Conmemoraciones Culturales, 2004), 1:49o-92; Giráldez, Age of Trade, 126.

8 Bayne, "Converting the Pacific," 2. 
Some scholars have argued that early modern representations of the Indies, which shaped European cultural encounters with the exotic animals, plants, and natives, must be understood as a colonial archive but also as a form of "translation": from one language to another, from one place to the other, from a lived experience to a written experience. ${ }^{9}$ How did cosmopolitanism, cross-cultural exchanges, and circulation of knowledge challenge center-periphery dynamics? What role did Iberian transoceanic empires play in the strengthening of wide-ranging and multidirectional missionary networks designed from Rome? And conversely, what is the importance that missionary networks had in forging a religious vision of global empires? And how did the church corporations adapt their evangelizing project as a result of the interplay between local conditions and long-distance connections?

In this sense, Verónica Peña (UAB, Barcelona) focuses on the crucial role that Jesuits played in spreading crops, eating practices, and culinary material culture in the Mariana Islands. From 1668 onwards, food became a central concern for the missionaries involved in the evangelization of this Oceanic archipelago. According to Diego Luis de San Vitores (1627-72), the founder of the mission, the introduction of new crops, animals, and culinary equipment was vital to ensure the success of his evangelical project. In addition, San Vitores attempted to create a self-sufficient mission by promoting the practice of agriculture and animal husbandry among the CHamoru people. In other words, in the Marianas, Jesuit missionaries not only strove to reproduce their cuisine, but to recreate their entire food system. Firstly, Peña analyzes the local and global factors affecting the missionaries' goals and activities during the first six years of the mission (1668-74). More specifically, it shows that CHamoru resistance to Spanish intrusion the unreliability of maritime trade routes, the conflicts that arose inside the Jesuit order, and the tensions between the missionaries and the Spanish colonial authorities impeded the development of San Vitores's plans. Secondly, she explores the strategies that Jesuit missionaries followed to adjust their foodways to the social and physical environment of the Mariana Islands, paying attention to the process whereby missionaries adopted local foods. Finally, she argues that culinary accommodation-or "gastronomic accommodation," as Christine Oswald put it—was also applied

9 Joan-Pau Rubiés, Travel and Ethnology in the Renaissance: South India through European Eyes, 1250-1625 (Cambridge: Cambridge University Press, 2000); Ralph Bauer and Jaime Marroquín Arredondo, "Introduction: An Age of Translation," in Translating Nature: CrossCultural Histories of Early Modern Science, ed. Jaime Marroquín Arredondo and Ralph Bauer (Philadelphia: University of Pennsylvania Press, 2019), 1-23. 
as a political strategy in order to ease tensions and forge alliances with the indigenous population.

Finally, this special issue examines a meta-history of Iberian globalization and empire, which emphasized a failed hegemony over Islamic territories of southern Philippines as much as diminished the native Filipino as historical subject. In focusing upon these fundamental features, this theme dwells on ecclesiastical narratives (Coello, Rodríguez) as a better way to understand the dual notion of colonial authority and power-temporal and spiritualon which the Spanish commonwealth was founded. By the mid-seventeenth century, however, Muslim sultanates from the southern islands of Mindanao and Sulu persisted in their raids on the provinces of the Bisayan islands while other state-sponsored Western empires (mainly English and Dutch competitors) began to encroach on the so-called "Spanish Lake" $(1513-1607),{ }_{10}^{10}$ which challenged Iberian forms of colonial hegemony in the central Pacific. ${ }^{11}$ To what extent Spanish-"Moro" confrontation during the period of Iberian Union (158o1640) concealed cross-cultural interactions between Iberians and Muslims in southern Philippines? Was it echoing centuries of Iberian struggle (Reconquista) against Islam? How did Western normative assumptions about racial and religious differences imposed on to the natives in the Philippines? And how did local conditions shape Western regulations during early modern times?

In the first place, Alexandre Coello (UPF/CSIC-ICREA Academia) examines an unpublished Jesuit report: the Relación de las islas Filipinas (The report of the Filipino islands; Manila, 1654), by the Jesuit Juan Francisco Combés (1620-65). The objective was twofold. First, to inform the new governor of the Philippines, don Sabiniano Manrique de Lara (in office 1653-63), about the natural and moral peculiarities of the islands. Secondly, to convince him to leave definitively the military strongholds in the Moluccas. The colonial church never exercised a stable or long-lasting form of control over the

10 William Lytle Schurtz, "The Spanish Lake," Hispanic American Historical Review 2 (1922): 181-94; Oskar H. K. Spate, The Spanish Lake (Minneapolis: Minnesota University Press, 1979); Henry Kamen, Empire: How Spain Became a World Power, 1492-1763 (New York: Harper Collins, 2003); Buschmann, Slack, and Tueller, eds., Navigating the Spanish Lake, 17-36. As Chaplin pointed out, "the term 'Spanish Lake', for the Pacific Ocean, captures Spain's sense of seaborne proprietorship, though the designation also reflects ignorance that other people lived on islands and landmasses within the Pacific, as well as denial of the ocean's massively un-lakelike extent" (Joyce E. Chaplin, "The Pacific before Empire, c. 1500-180o," in Pacific Histories: Ocean, Land, People, ed. David Armitage and Alison Bashford [London: Palgrave Macmillan, 2014], 58 .

11 Matt. K. Matsuda, "AHR Forum: The Pacific," in "Oceans of History: Introduction," ed. Karen Wigen, The American Historical Review 111, no. 3 (2006): 761-63, https://doi.org/10.1086/ ahr.111.3.758 (accessed October 30, 2021). 
Islamic territories in southern Philippines. As a result, Combés asked Governor Manrique de Lara to reinforce the military presidios located in the southern islands of Mindanao, like that of San José de Zamboanga. As an afterword, this paper analyzes the martyrdom of the Jesuits Alejandro López (1604-55) and Juan de Montiel $\left(163^{2-55}\right)$ as a culmination of the missionary experience in Mindanao. Their diplomatic activities in the court of Muhammad Dipatwān Qudrāt (or Kudarat) were part of a complex process of occupation of the border areas in the southern Philippines to stop the ongoing Muslim raids.

In the second place, Eberhard Crailsheim (csic, Madrid) centers on the Jesuit presence in the nearby island of Mindanao (1718-68). After leaving the military strongholds in Mindanao (1662), the Jesuits re-established its abandoned missions in 1718 , following a royal decree. The next fifty years represented a very dynamic succession of different events in which they played a distinctive role. First, Crailsheim briefly outlines the role of the Jesuit missionaries in Mindanao during these years and introduces some outstanding episodes. Secondly, he reflects on the way in which Jesuit activities were represented and published in Manila and also in other parts of the Spanish Pacific imperium. Finally, this paper develops a distinct view on the Jesuit presence in the south of the Philippines, how they were characterized, and how they depicted themselves in the years prior to their expulsion between 1768 and 1771 .

Finally, Ana $\mathrm{M}^{\mathrm{a}}$ Rodríguez-Rodríguez (University of Iowa, USA) analyzes the representation of St. Francis Xavier in Spanish texts. As she points out, his figure was used as an instrument to increase the prestige and dissemination of colonial endeavors. In the seventeenth century, amidst the tense rivalry between the Spanish and the Portuguese empires, several Jesuit writings take a stand in their support of the Spanish monarchy's interests in Asia reinforcing the legitimacy of its conquests and the appropriateness of Spain's intervention in the area. Rodríguez's contribution explores two of these texts: Diego de Bobadillas's (1590-1648) Relación de las gloriosas victorias (Report of the glorious victories), and Diego Calleja's (1638-1725) San Francisco Javier, el Sol en Oriente (St. Francis Xavier, the sun in the East), focusing on the textual strategies employed therein to vindicate the fight against Muslims in the Philippines and the wider Spanish intervention in Pacific through the celebration of St. Francis's endeavors.

All things considered, these articles bring into convergence the political, economic, religious, and diplomatic currents of early modern history and culture overseas, paying special attention to the centrality of the Jesuits as agents in the making of the modern world, with particular attention to the "conversion" (both religious and cultural) of the trans-Pacific frontier into a zone of sustained contact and transculturation involving Europe, Asia, and the Americas. 